\title{
Fresh-market Tomato Gas Exchange, Biomass, and Fruit Yield are Similar with Legume Cover Crops or Synthetic Nitrogen Fertilizer
}

\author{
W.F. Whitehead ${ }^{1}$ and B.P. Singh \\ Agricultural Research Station, Fort Valley State University, Fort Valley, \\ GA 31030-4313
}

Additional index words. cover crop, nitrogen fertilization, tomato production, legume, nonlegume, leaf-area index, gas exchange

\begin{abstract}
Conventional production of tomatoes (Lycopersicon esculentum Mill.) requires substantial investments, intensive management and high inputs of nitrogen. High $\mathrm{N}$ rates invariably leave residual soil $\mathrm{NO}_{3}-\mathrm{N}$ with the potential of polluting ground water and posing health hazard to humans and animals. The objective of this study was to examine the value of cover crops as a substitute to synthetic $\mathbf{N}$ fertilizer in growing of tomatoes. The experimental treatments consisted of control (no $\mathrm{N}$ fertilizer or cover crop), Abruzzi rye (Secale cereale $\mathrm{L}$ ), hairy vetch (Vicia villos a Roth), or crimson clover (Trifolium incarnatum L.) cover crop, and fertilization of $\mathrm{N}$ at 90 or $180 \mathrm{~kg} \cdot \mathrm{ha}^{-1}$. The treatments were replicated four times over 2 years in a randomized complete block experiment for growing 'Mountain Pride' tomato on a Greenville fine sandy loam soil. The parameters used to evaluate the performance of tomato consisted of leaf area index (LAI), gas exchange (GE), above ground plant dry weight, number of fruits, dry weight of fruits, and marketable fruit yield. Tomato LAI was similar under legumes and $\mathbf{N}$ fertilizers. Hairy vetch and applied $\mathrm{N}$ at $90 \mathrm{~kg} \cdot \mathrm{ha}^{-1}$ influenced net photosynthesis $\left(P_{\mathrm{n}}\right)$ and transpiration $(E)$ the most in both years at all stages of growth. Highest number of tomatoes were produced in hairy vetch and applied $\mathrm{N}$ at $90 \mathrm{~kg} \cdot \mathrm{ha}^{-1}$ plots. There was no significant difference in the above ground plant dry weight, fruit yield and dry weight of fruits between legumes and $\mathbf{N}$ fertilizers. The results suggested that the legume cover crops compared favorably to $\mathbf{N}$ fertilizers in promoting tomato growth and development and may have potential of substituting $\mathbf{N}$ fertilizers in fresh-market tomato production.
\end{abstract}

Conventional production of tomatoes requires initial high investments, intensive management and high inputs of N (Univ. of Georgia, 1995). Additional $\mathrm{N}$ is commonly applied in the form of a synthetic fertilizer and is one of the main inputs in agriculture today. Groundwater contamination from residual soil $\mathrm{NO}_{3}-\mathrm{N}$ is a major concern because of its potential health hazard to humans and animals (Dorsch et al., 1984; Nielsen and Lee, 1987). The U.S. Environmental Protection Agency (EPA) has identified agriculture as the largest nonpoint source of water pollution (Hallberg et al., 1985; NRC, 1989). Hallberg (1989) reported that excessive use of synthetic $\mathrm{N}$ fertilizer plus poor soil and crop management practices increased $\mathrm{NO}_{3}-\mathrm{N}$ pollution of groundwater. Furthermore, when the land is left fallow during fall and winter in conjunction with above average rainfall and low evapotranspiration, residual $\mathrm{NO}_{3}-\mathrm{N}$ can leach beyond the soil profile (Campbell et al., 1984; Sainju et al., 1998). Therefore, low input sustainable practices which improve $\mathrm{N}$ use efficiency, water, and soil qualities are needed for producing tomatoes.

The availability of a suitable $\mathrm{N}$ source in many agricultural situations has been reported Received for publication 5 Nov. 2003. Accepted for
publication 28 June 2004.
${ }^{1}$ Corresponding author; e-mail whitehew @ fvsu.
edu.

HortScience Vol. 40(1) February 2005

type of $\mathrm{N}$ input could result in farming practices that are economically sound and environmentally responsible (Bohlool et al., 1992; Giller and Cadisch, 1995; Vance, 1997).

Before the widespread use of synthetic chemicals, cover crops were extensively used to recycle nutrients, improve and add $\mathrm{N}$ to the soil (Fred et al., 1932; Frye et al., 1985). Cover crops planted in the fall after summer crops, provides a vegetative cover for bare soils and thus protect it from erosive forces while decreasing leaching by scavenging residual $\mathrm{NO}_{3}-\mathrm{N}$ (Meisinger et al., 1991; Power and Doran, 1988; Sainju et al., 1998; Smith et al., 1987;). Availability of cover crop nitrogen to the succeeding principal crop depends on the type of cover crop.

A legume cover crop biologically fixes nitrogen and can provide substantial amounts of $\mathrm{N}$ to the succeeding crop (Frye et al.,1988; Hargrove, 1986; Vigil and Kissel, 1991). Non-legumes like rye and ryegrass (Lolium multiflorum Lam.) do not provide nitrogen, but are better scavengers of residual $\mathrm{NO}_{3}-\mathrm{N}$ than hairy vetch (Kuo et al., 1995). Hairy vetch is a legume cover crop which can enrich soil $\mathrm{N}$ and increase tomato yield compared to non-legume or no cover crop (Abdul-Baki and Teasdale, 1993; Teasdale and Abdul-Baki, 1995). McVay et al.(1989) reported that hairy vetch and crimson clover contributed $\mathrm{N}$ on average 123 and $99 \mathrm{~kg} \cdot \mathrm{ha}^{-1}$, respectively, while Sainju and Singh (1997) reported that winter cover crops increased yield of succeeding summer crops equivalent to that produced by $\mathrm{N}$ fertilization rates at 15 to $200 \mathrm{~kg} \cdot \mathrm{ha}^{-1}$.

One of the important vegetable crops produced in Georgia is tomato (Univ. of Georgia, 1995). Conventional tomato production requires intensive management and high inputs of $\mathrm{N}$. This type of practice is prone to $\mathrm{N}$ leaching(Power and Scepers, 1989). In addition, tomato is lower in its ability to recover $\mathrm{N}$ compared to cereal crops, which provides more potential for $\mathrm{N}$ leaching (Creamer et al., 1996; Lowrance and Smittle, 1988; Sweeney et al., 1987). Furthermore, the biological and economic yield of a crop is associated with the rate of net $\mathrm{CO}_{2}$ exchange per unit leaf area (Hobbs and Mahon, 1982; Zelitch,1982). Under N-limiting conditions tomato leaf photosynthesis is typically reduced $30 \%$ or less and under severe $\mathrm{N}$ stress tomato LAI, biomass, and fruit yield is reduced $60 \%$ to $70 \%$ (Scholberg et al. , 2000).

Since commercial tomato production requires high $\mathrm{N}$ inputs, there is a need to develop alternative cultural practices that are more environmentally benign than conventional, petrochemical-based systems. Research is needed in developing a production system that reduces $\mathrm{N}$-fertilizer use and protects ground water quality without reducing yield. Little is known about the effects of cover crops in comparison to $\mathrm{N}$ fertilizers on growth, physiological activities and fruit yield of tomatoes. The objective of this study is to evaluate the effect of cover crops vis-a-vis synthetic N fertilizer on aboveground plant growth, LAI, $\mathrm{GE}$ and fruit yield of tomatoes.

\section{Materials and Methods}

This study was conducted from 1995 to 1997 at the Fort Valley State University Agricultural Research Station, Fort Valley, Ga., located at $32^{\circ} 34^{\prime} \mathrm{N}, 83^{\circ} 52^{\prime} \mathrm{W}$. Soil type at the experimental site was Greenville fine sandy loam (fine-loamy, kaolinitic, thermic, Rhodic Kandiudults).

Experiment consisted of six treatments [applied $\mathrm{N}$ at 0 (control), 90, $180 \mathrm{~kg} \cdot \mathrm{ha}^{-1}$, abruzzi rye, hairy vetch, and crimson clover] arranged in a randomized complete block design with four replications. Plot size was 4.5 $\times 7.2 \mathrm{~m}$. All plots received no herbicide and pesticides or $\mathrm{N}-\mathrm{P}-\mathrm{K}$ fertilization during the fall and winter, with $\mathrm{N}$ at 0 (control), 90, and $180 \mathrm{~kg} \cdot \mathrm{ha}^{-1}$ plots always being fallow. During the fall of each year, cover crops were planted in the same plots.

Fall seed beds were prepared 18 Sept. 1995 and 11 Oct. 1996 by disk harrowing first and then smoothing with a S-tine. Cover crops were drilled at $28 \mathrm{~kg} \cdot \mathrm{ha}^{-1}$ for hairy vetch, $25 \mathrm{~kg} \cdot \mathrm{ha}^{-1}$ 
for crimson clover, and $80 \mathrm{~kg} \cdot \mathrm{ha}^{-1}$ for abruzzi rye at a $15-\mathrm{cm}$ row spacing. Before drilling the vetch was innoculated with Rhizobium leguminosarum (bv. Viceae) and crimson clover with R. trifolii. At flowering, cover crop and fallow plots were harvested during mid-April 1996 and 1997 for biomass yield (data presented elsewhere). After subsample collection, plant residue was uniformly spread back over where it was harvested with follow up rotary mowing of the site and residue soil incorporation by disk harrowing. Incorporated residue was allowed to biodegrade for 2 weeks to synchronize $\mathrm{N}$ release and minimize alleopathic effects at time of tomato transplant.

At the end of April in 1996 and 1997, triple superphosphate $\left[\mathrm{Ca}\left(\mathrm{H}_{2} \mathrm{PO}_{4}\right)_{2}, 46 \% \mathrm{P}\right]$ at the rate of $122 \mathrm{~kg} \cdot \mathrm{ha}^{-1}$ and muriate of potash $(\mathrm{Kcl}$, $60 \% \mathrm{~K})$ at the rate of $93 \mathrm{~kg} \cdot \mathrm{ha}^{-1}$ were applied to all plots. At the same time, $3.35 \mathrm{~kg} \cdot \mathrm{ha}^{-1}$ of diazinon [diethyl-0-(2-isopropyl-6-methyl-4pyrimidinyl] to control terrestrial pests and 0.57 $\mathrm{kg} \cdot \mathrm{ha}^{-1}$ of trifluralin [2,6-dintro-N-dipropyl4- (trfluoromethyl)benzeneamine] to control weeds were also applied. The agricultural chemicals were incorporated by disking and the plots smoothed with harrow for planting. A plot consisted of five rows $7.2 \mathrm{~m}$ long. Fourweek-old 'Mountain Pride' tomato seedlings were transplanted east-west at $0.9 \mathrm{~m}$ within and between row spacings. After one week, 4.7 $\mathrm{L} \cdot \mathrm{ha}^{-1}$ of starter solution consisting of $3 \mathrm{~N}-17 \mathrm{P}-5 \mathrm{~K}$ was applied to the seedlings to support root growth and early establishment. Nitrate of soda $\left(\mathrm{NaNO}_{3}\right)$ at 180 and $90 \mathrm{~kg} \cdot \mathrm{ha}^{-1}$ of applied $\mathrm{N}$ were split applied three times at three week intervals to the designated plots. All plots were irrigated by an overhead reel rain gun with $25-50 \mathrm{~mm}$ of water after planting, $\mathrm{N}$ fertilization and at periods of low rainfall.

From mid-July to mid-August tomato fruits were harvested every 3 to $4 \mathrm{~d}$ from the same five randomly chosen plants in the two middle rows. Fresh fruit weights were recorded each harvest. Fresh market yield was determined by adding all fruit harvests obtained during the season. After final harvest, fruit number and dry weight plant components were determined from tomato plants cut $2 \mathrm{~cm}$ above ground and separated by fruit, stem and leaves for air- oven drying at $60^{\circ} \mathrm{C}$.

A plant canopy analyzer (LAI-2000; LICOR, Lincoln, Nebr.)was used to estimate LAI at three monthly intervals from 5 June to 24 Aug. for both years at flowering, mid-fruiting, and final fruiting. Each data set consisted of one above-canopy irradiance reading and four below-canopy readings about $15 \mathrm{~cm}$ above the soil along an evenly spaced diagonal transect between the two middle yield rows of each plot.

The GE (gas exchange) data were recorded at three monthly intervals generally following same time line described for LAI. Gas exchange parameters were transpiration $(\mathrm{E}$, $\left.\mathrm{mmol} \cdot \mathrm{m}^{-2} \cdot \mathrm{s}^{-1}\right)$ and net photosynthesis $\left(\mathrm{P}_{\mathrm{n}}, \mu \mathrm{mol}\right.$ $\mathrm{CO}_{2} / \mathrm{m}^{2} / \mathrm{s}$ ). Measurements were recorded by a portable steady-state infrared gas-exchange system (LCA-2; Analytical Development, Huddleston, England). The two newest fully expanded leaves on two randomly selected yield row plants were used to obtain nondestructive gas-exchange readings. Data were collected between 0900 and 1300 HR solar time, when photosynthetic active radiation (PAR) ranged between 1277 and $1895 \mu \mathrm{mol} \cdot \mathrm{m}^{-2} \cdot \mathrm{s}^{-1}$ and ambient temperature ranged between 25 to $34^{\circ} \mathrm{C}$.

The rainfall and air temperature data for this study period were collected from the GeorgiaAutomated Environmental Monitoring Network weather station located about $50 \mathrm{~m}$ from the site. Air temperatures were measured at $1.5 \mathrm{~m}$ above ground.

All data were subjected to analysis of variance using The GLM procedure (SAS Institute,
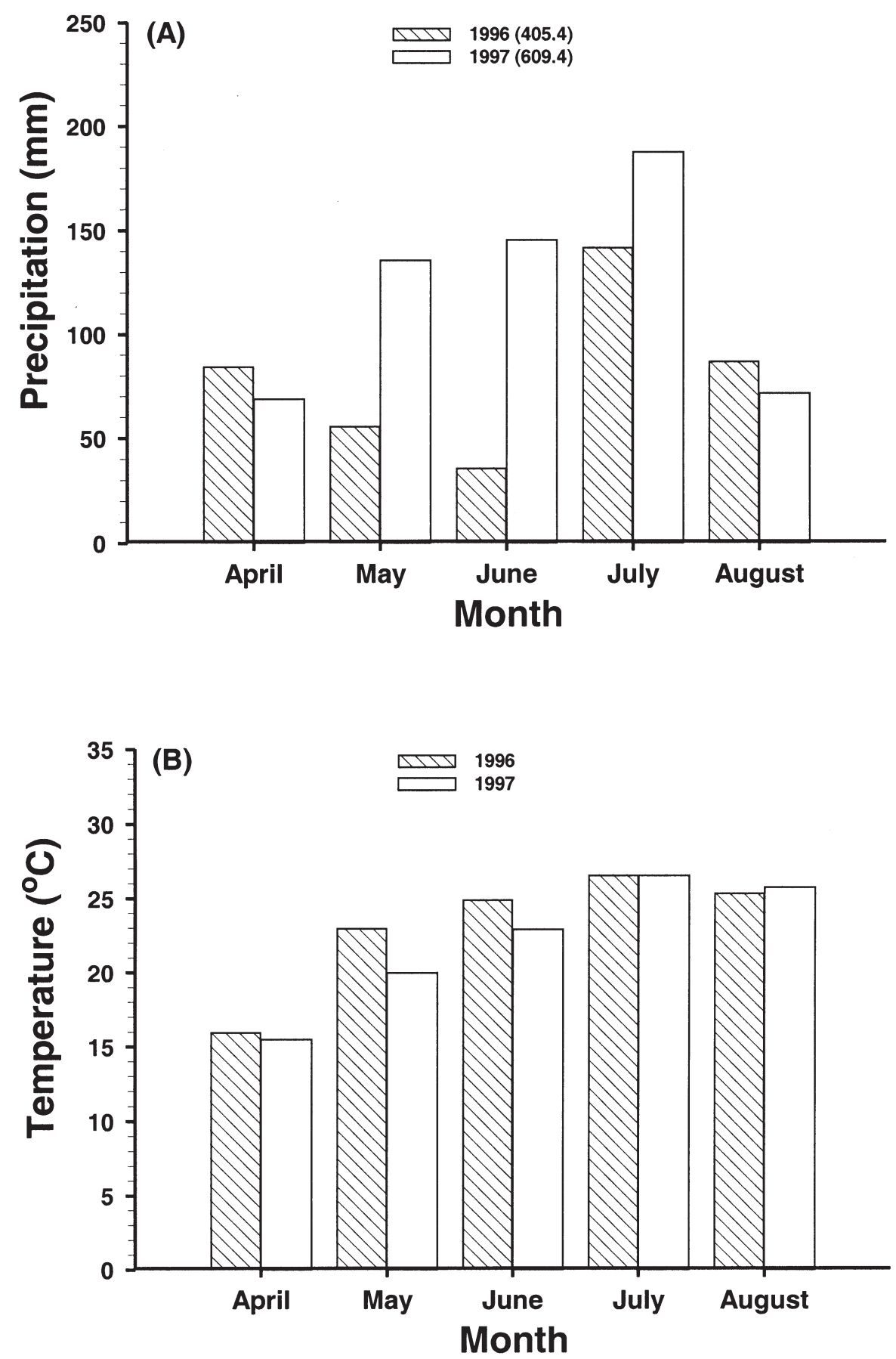

Fig. 1. Total monthly precipitation (A) and average monthly temperature (B) from April to August in 1996 and 1997. Parenthetical numbers represents total precipitation from April to August in specified year. 
moisture stress, since irrigation was applied during periods of low rainfall. The average monthly temperature over both years ranged from about $16.0^{\circ} \mathrm{C}$ in April to $26.0^{\circ} \mathrm{C}$ in July (Fig.1B). The growing season in 1996 was warmer than 1997.

Aboveground biomass and fresh-market tomato yield. Hairy vetch and crimson clover produced significantly higher tomato aboveground biomass weight and fresh fruit yield compared to the abruzzi rye and $\mathrm{N}$ at $0 \mathrm{~kg} \cdot \mathrm{ha}^{-1}$. The legume cover crops affected biomass weight and fruit yield similar to $\mathrm{N}$ at 180 and $90 \mathrm{~kg} \cdot \mathrm{ha}^{-1}$. There was no significant difference between $\mathrm{N}$ at 180 or $90 \mathrm{~kg} \cdot \mathrm{ha}^{-1}$ on their effect on biomass weight or fruit yield. Rye and $\mathrm{N}$ at $0 \mathrm{~kg} \cdot \mathrm{ha}^{-1}$ produced similar biomass weight and fruit yield. Above ground biomass and fruit yield in 1996 was $13 \%$ and $27 \%$, respectively greater than 1997 . The effect of
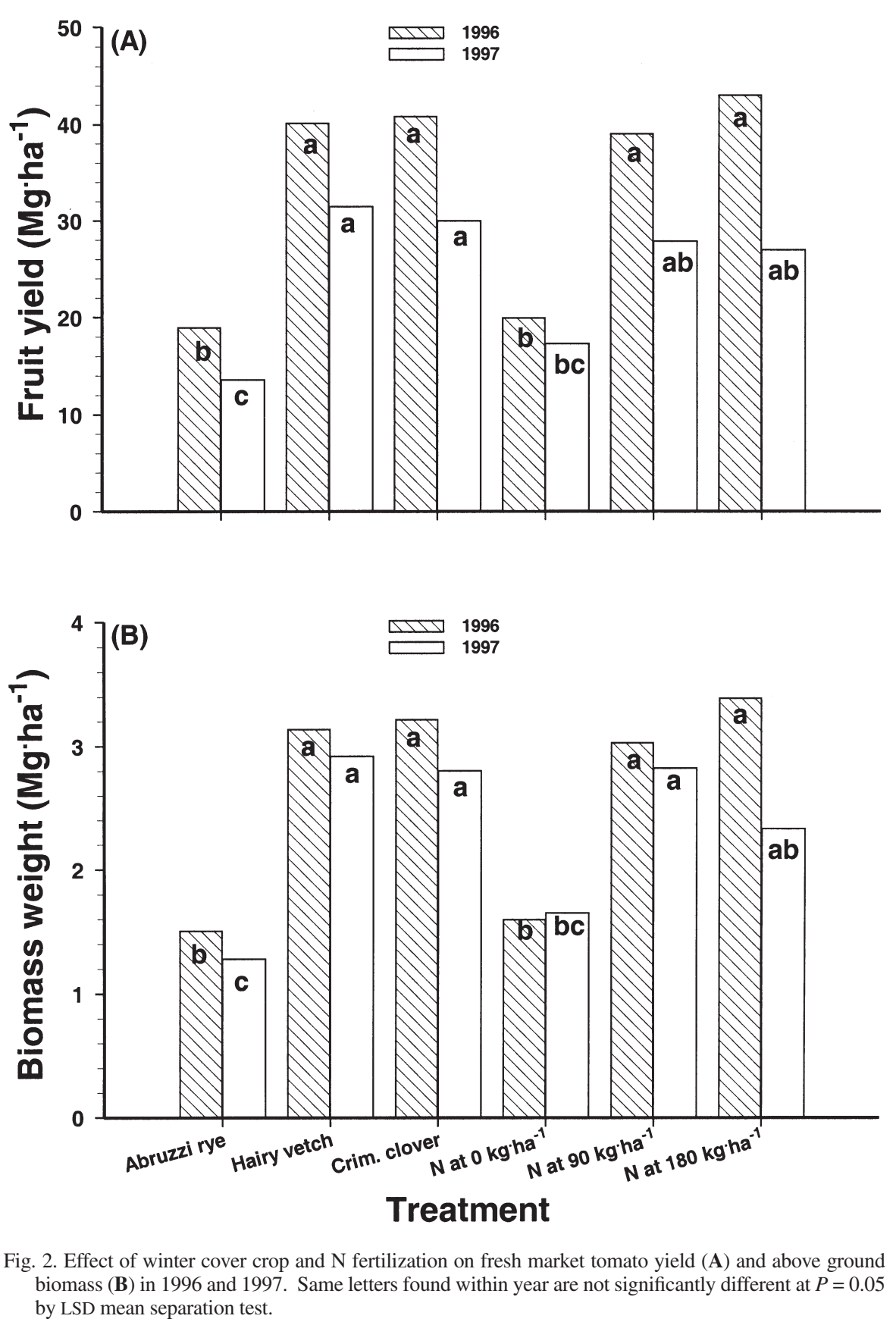

Fig. 2. Effect of winter cover crop and $\mathrm{N}$ fertilization on fresh market tomato yield (A) and above ground biomass (B) in 1996 and 1997. Same letters found within year are not significantly different at $P=0.05$ by LSD mean separation test.

treatments on the two parameters also showed year-to-year variation. Highest biomass weight $\left(3.39 \mathrm{Mg} \cdot \mathrm{ha}^{-1}\right)$ and fruit yield $\left(43.1 \mathrm{Mg} \cdot \mathrm{ha}^{-1}\right)$ in 1996 were produced by $\mathrm{N}$ at $180 \mathrm{~kg} \cdot \mathrm{ha}^{-1}$, while highest biomass weight $\left(2.92 \mathrm{Mg} \cdot \mathrm{ha}^{-1}\right)$ and fruit yield (31.5 Mg.ha- $\left.{ }^{-1}\right)$ in 1997 resulted from hairy vetch (Fig. 2A and B). The lower yield during 1997 could be due to excessive rainfall during fruiting season (16\% more rainfall fell in JuneAugust for 1997 compared to the 41 years average and $35 \%$ more rainfall fell in June-August for 1997 compared to 1996) causing leaching of labile $\mathrm{NO}_{3}-\mathrm{N}$ from the top soil.

The higher biomass weight and fruit yield produced by hairy vetch and crimson clover compared to the rye and $0 \mathrm{~N}$ treatments is attributed to supplemental biologically-fixed $\mathrm{N}$ supplied by the two legumes to the succeeding tomato crop against rye and bare fallow with no such capability (Abdul-Baki et al., 1996;

HortScience Vol. 40(1) February 2005
Sainju and Singh, 1997). Others, have also reported greater tomato yield and biomass with hairy vetch than bare fallow. No differences among hairy vetch, crimson clover, $\mathrm{N}$ at 90 and $180 \mathrm{~kg} \cdot \mathrm{ha}^{-1}$ for biomass weight and fruit yield indicate that these treatments adequately met the nitrogen need of tomato crop. McVay et al. (1989) reported that hairy vetch and crimson clover contribute $\mathrm{N}$ an average of 123 and 99 $\mathrm{kg} \cdot \mathrm{ha}^{-1}$, respectively to the succeeding crop.

Tomato fruit number and dry weight per plant. Total fruit number per plant was pooled over year because treatment $\times$ year interaction was not different, while fruit dry weight is presented by year since its interaction was significantly different. Highest fruit number (33.3) was produced by $\mathrm{N}$ at $90 \mathrm{~kg} \cdot \mathrm{ha}^{-1}$ treatment and lowest (15.2) by abruzzi rye (Fig. 3A). This, however, contradicts Sainju et al. (2000) who found no influence of cover crop and $\mathrm{N}$ fertilization on tomato fruit number.

In 1996, highest fruit dry weight (176.3 $\mathrm{g} /$ plant) resulted from $\mathrm{N}$ at $180 \mathrm{~kg} \cdot \mathrm{ha}^{-1}$, while in 1997 the highest fruit dry weight (180.75 $\mathrm{g} /$ plant) was produced by $\mathrm{N}$ applied at 90 $\mathrm{kg} \cdot \mathrm{ha}^{-1}$ (Fig. 3B). Legumes and Both rates of $\mathrm{N}$ fertilization and legumes produced significantly greater fruit dry weight than abruzzi rye or $0 \mathrm{~N}$. Hairy vetch and crimson clover influence fruit dry weight comparable to the $\mathrm{N}$ fertilizer rates probably because of similar amounts of available $\mathrm{N}$ being produced by the legume cover crops.

Leaf area index. Data is presented by year and growth stage because they interacted differently for LAI. Average LAI in 1996 was $25 \%$ less than 1997. In 1996, maximum LAI (3.63) was produced by $\mathrm{N}$ at $90 \mathrm{~kg} \cdot \mathrm{ha}^{-1}$ at mid fruiting and lowest (0.84) at late fruiting by abruzzi rye (Table 1). In 1997, highest LAI value (3.04) also occurred during mid fruiting but by hairy vetch and lowest (0.59) at flowering by abruzzi rye (Table 1 ). LAI at mid fruiting was significantly greater than flowering and then declined to late fruiting. LAI values within year and growth stage for hairy vetch, crimson clover, $\mathrm{N}$ at 90 and $180 \mathrm{~kg} \cdot \mathrm{ha}^{-1} \mathrm{did} \mathrm{not}$ differ significantly from one another. Within each year and growth stage, abruzzi rye and $0 \mathrm{~N}$ treatments had lowest values and generally did not differ between each other. These results agree with Scholberg et al. (2000), who reported that LAI increased with increase in $\mathrm{N}$ supply and was associated with increases in mean leaf size and number.

Gas-exchange rates. GE data is presented by year and growth stage because interactions for $\mathrm{E}$, and $\mathrm{P}_{\mathrm{n}}$ differed significantly. The $\mathrm{P}_{\mathrm{n}}$ rates in 1997 was lower than 1996. This may have been due to the leaching of $\mathrm{N}$ during fruiting period in 1997 as a result of heavy rainfall. In 1996 and 1997 highest $P_{n}$ (22.79 and 9.15 $\mu \mathrm{mol} \cdot \mathrm{m}^{-2} \cdot \mathrm{s}^{-1}$, respectively) occurred at mid fruiting by $\mathrm{N}$ at 180 and $90 \mathrm{~kg} \cdot \mathrm{ha}^{-1}$ treatments, respectively, while lowest $P_{n}$ values (10.25 and $0.81 \mu \mathrm{mol} \cdot \mathrm{m}^{-2} \cdot \mathrm{s}^{-1}$, respectively) were produced at the late fruiting stage by $0 \mathrm{~N}$ (Table 2). Maximum E values for 1996 and 1997 (11.08 and $14.34 \mathrm{mmol} \cdot \mathrm{m}^{-2} \cdot \mathrm{s}^{-1}$, respectively) were obtained at mid-fruiting by $\mathrm{N}$ at $90 \mathrm{~kg} \cdot \mathrm{ha}^{-1}$, while lowest values $\left(8.32\right.$ and $8.09 \mathrm{mmol} \cdot \mathrm{m}^{-2} \cdot \mathrm{s}^{-1}$, 
respectively) occurred at flowering with abruzzi rye and $0 \mathrm{~N}$ treatments, respectively (Table 3). In 1996, $P_{n}$ increased from flowering to mid fruiting then decreased to late fruiting for only the legume and $\mathrm{N}$ fertilization treatments, while in 1997 all treatments decreased across all growth stages except for $\mathrm{N}$ at $90 \mathrm{~kg} \cdot \mathrm{ha}^{-1}$ treatment. However, E increased from flowering to mid fruiting and then decreased to late fruiting in both years. In 1996, average $\mathrm{P}_{\mathrm{n}}$ for each growth stage was $57 \%, 67 \%$, and $86 \%$ greater than associated 1997 growth stages. Average values of E in 1996 at flowering and late fruiting were 3\% and 9\% greater than 1997 associated values, but $24 \%$ lower at mid-fruiting. Generally, abruzzi rye and $0 \mathrm{~N}$ treatments had lowest GE values and did not differ from one another (Tables 2 and 3). Rye produced exceptions to this in 1997 at flowering for $\mathrm{P}_{n}$ and $\mathrm{E}$, in 1996 for $\mathrm{E}$ at mid fruiting, and for $\mathrm{E}$ in 1997 at flowering and late fruiting. Net Photosynthesis within each year and growth stage for hairy vetch, crimson clover, $\mathrm{N}$ at 90 and $180 \mathrm{~kg} \cdot \mathrm{ha}^{-1}$ treatments were usually similar among themselves except for crimson clover and $\mathrm{N}$ at $90 \mathrm{~kg} \cdot \mathrm{ha}^{-1}$ during mid and late fruiting in both years. Transpiration values were also generally alike, except for crimson clover at 1996 flowering and $1997 \mathrm{mid}$ fruiting, for $\mathrm{N}$ at $180 \mathrm{~kg} \cdot \mathrm{ha}^{-1}$ at 1996 flowering and late fruiting, and for $\mathrm{N}$ at 180 and $90 \mathrm{~kg} \cdot \mathrm{ha}^{-1}$ at 1997 flowering.

Similar to above results, Boote and Pickering (1994) has reported that relative leaf photosynthesis is reduced if $\mathrm{N}$ concentration is not at optimum concentration while Scholberg et al. (2000) found that photosynthesis averaged $73 \%$ of the observed maximum rate when leaf $\mathrm{N}$ concentrations were in the deficient range.

The results of this study showing tomato fruit yield, biomass, plant growth components, LAI, and GE were affected by hairy vetch, crimson clover, and $\mathrm{N}$ fertilizer treatments similarly, indicate that the legume cover crops are comparable to synthetic $\mathrm{N}$ rates in sustaining tomato gas exchange, plant growth and fruit production. Similar performance of tomatoes under abruzzirye and control suggests $\mathrm{N}$ fertilization rate for tomato after nonlegume cover crop should be similar to fields kept fallow during winter.
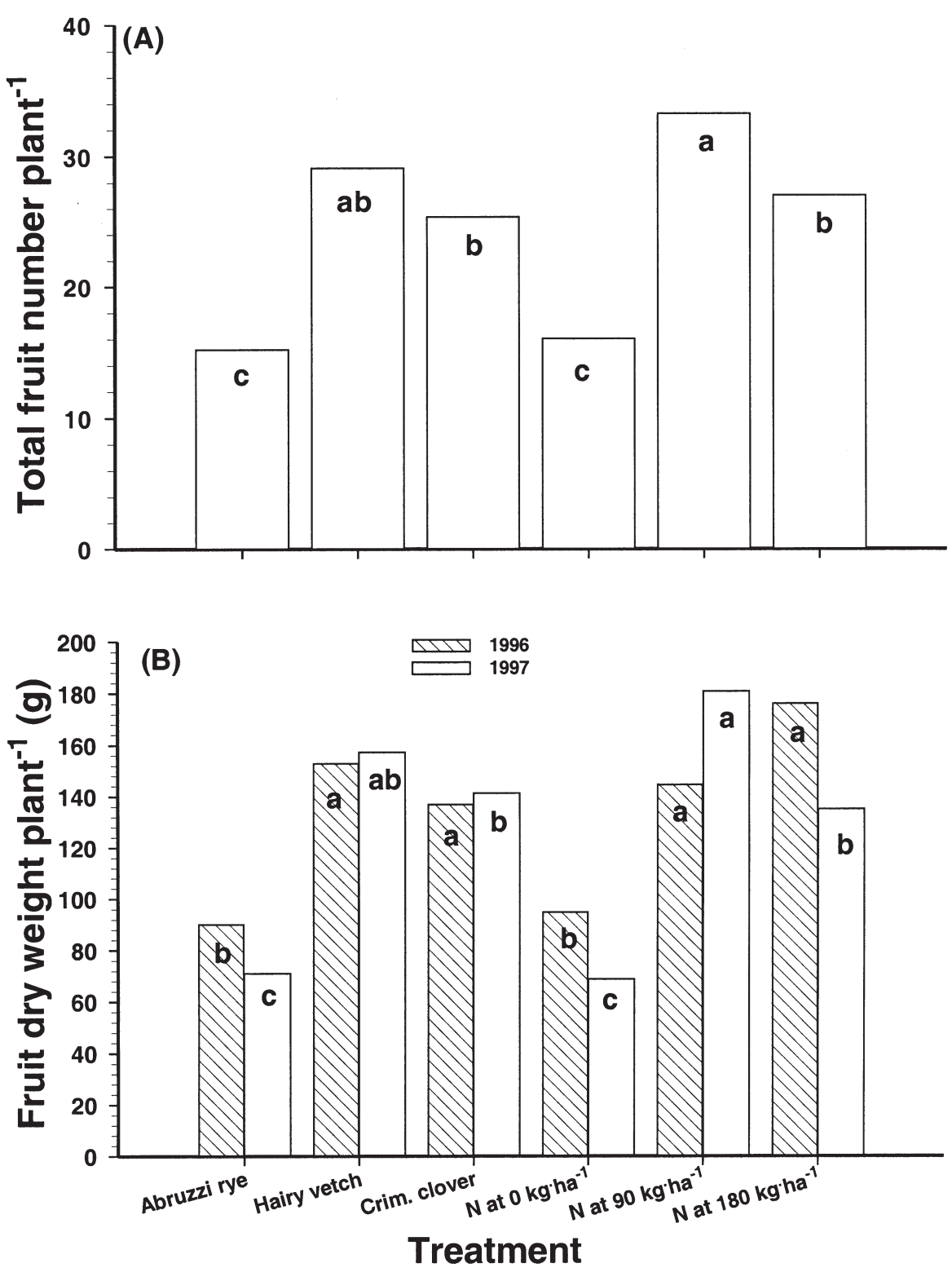

Fig. 3. Effect of winter cover crop and $\mathrm{N}$ fertilization on total fruit number (A) pooled over year and fruit dry weight (B) in 1996 and 1997. Same letters found within year are not significantly different at $P=0.05$ by LSD mean separation test.

Table 1. Effect of winter cover crop and $\mathrm{N}$ fertilization on leaf area index (LAI) of tomatoes at three growth stages $(\mathrm{F}=$ flowering, $\mathrm{MF}=$ mid-fruiting, $\mathrm{LF}=$ late fruiting $)$ in 1996 and 1997.

\begin{tabular}{|c|c|c|c|c|c|c|}
\hline \multirow[b]{3}{*}{ Treatment } & \multicolumn{6}{|c|}{ LAI } \\
\hline & \multicolumn{3}{|c|}{1996} & \multicolumn{3}{|c|}{1997} \\
\hline & $\mathrm{F}$ & MF & LF & $\mathrm{F}$ & $\mathrm{MF}$ & LF \\
\hline Control (0N) & $1.29 \mathrm{a}^{\mathrm{z}}$ & $1.62 \mathrm{c}$ & $1.03 \mathrm{bc}$ & $0.82 \mathrm{~cd}$ & $1.83 \mathrm{~b}$ & $1.06 \mathrm{~b}$ \\
\hline $\mathrm{N}$ at $90 \mathrm{~kg} \cdot \mathrm{ha}^{-1}$ & $1.45 \mathrm{a}$ & $3.63 \mathrm{a}$ & $1.50 \mathrm{a}$ & $1.06 \mathrm{bc}$ & $2.86 \mathrm{a}$ & $1.59 \mathrm{a}$ \\
\hline $\mathrm{N}$ at $180 \mathrm{~kg} \cdot \mathrm{ha}^{-1}$ & $1.21 \mathrm{ab}$ & $2.69 \mathrm{~b}$ & $1.31 \mathrm{ab}$ & $1.16 \mathrm{ab}$ & $2.82 \mathrm{a}$ & $1.39 \mathrm{ab}$ \\
\hline Abruzzi rye & $0.93 \mathrm{~b}$ & $1.44 \mathrm{c}$ & $0.84 \mathrm{c}$ & $0.59 \mathrm{~d}$ & $1.98 \mathrm{~b}$ & $0.97 \mathrm{~b}$ \\
\hline Hairy vetch & $1.40 \mathrm{a}$ & $2.61 \mathrm{~b}$ & $1.43 \mathrm{a}$ & $1.29 \mathrm{ab}$ & $3.04 \mathrm{a}$ & $1.52 \mathrm{a}$ \\
\hline Crimson clover & $1.44 \mathrm{a}$ & $2.57 \mathrm{~b}$ & $1.36 \mathrm{ab}$ & $1.45 \mathrm{a}$ & $3.01 \mathrm{a}$ & $1.60 \mathrm{a}$ \\
\hline
\end{tabular}

${ }^{2}$ Numbers followed by the same letter within a column are not significantly different at $P=0.05$ by least significant differences test. 
Table 2. Effect of winter cover crop and $\mathrm{N}$ fertilization on net photosynthesis $(\mathrm{P})$ of tomatoes at three growth stages $(\mathrm{F}=$ flowering, $\mathrm{MF}=$ mid-fruiting, $\mathrm{LF}=$ late fruiting $)$ in 1996 and 1997.

\begin{tabular}{|c|c|c|c|c|c|c|}
\hline \multirow[b]{3}{*}{ Treatment } & \multicolumn{6}{|c|}{$\mathrm{P}_{\mathrm{n}}\left(\mu \mathrm{mol} \mathrm{CO} \mathrm{CO}_{2} / \mathrm{m}^{2} / \mathrm{s}\right)$} \\
\hline & \multicolumn{3}{|c|}{1996} & \multicolumn{3}{|c|}{1997} \\
\hline & $\mathrm{F}$ & MF & LF & $\mathrm{F}$ & $\mathrm{MF}$ & LF \\
\hline$\overline{\text { Control (ON) }}$ & $14.89 \mathrm{c}^{\mathrm{z}}$ & $14.18 \mathrm{c}$ & $10.25 \mathrm{c}$ & $5.43 \mathrm{c}$ & $3.41 \mathrm{c}$ & $0.81 \mathrm{c}$ \\
\hline $\mathrm{N}$ at $90 \mathrm{~kg} \cdot \mathrm{ha}^{-1}$ & $20.04 \mathrm{a}$ & $22.74 \mathrm{a}$ & $15.11 \mathrm{~b}$ & $8.52 \mathrm{ab}$ & $9.15 \mathrm{a}$ & $2.84 \mathrm{ab}$ \\
\hline $\mathrm{N}$ at $180 \mathrm{~kg} \cdot \mathrm{ha}^{-1}$ & $18.23 \mathrm{ab}$ & $22.79 \mathrm{a}$ & $17.97 \mathrm{a}$ & $8.39 \mathrm{ab}$ & $7.19 \mathrm{~b}$ & $2.66 \mathrm{~b}$ \\
\hline Abruzzi rye & $16.69 \mathrm{bc}$ & $15.28 \mathrm{c}$ & $10.26 \mathrm{c}$ & $7.33 \mathrm{~b}$ & $3.75 \mathrm{c}$ & $1.16 \mathrm{c}$ \\
\hline Hairy vetch & $20.37 \mathrm{a}$ & $21.98 \mathrm{ab}$ & $16.94 \mathrm{a}$ & $8.98 \mathrm{a}$ & $7.82 \mathrm{~b}$ & $3.71 \mathrm{a}$ \\
\hline Crimson clover & $18.89 \mathrm{a}$ & $20.38 \mathrm{~b}$ & $17.01 \mathrm{a}$ & $7.85 \mathrm{ab}$ & $7.28 \mathrm{~b}$ & $1.56 \mathrm{c}$ \\
\hline
\end{tabular}

${ }^{2}$ Numbers followed by the same letter within a column are not significantly different at $P=0.05$ by least significant differences test.

Table 3. Effect of winter cover crop and $\mathrm{N}$ fertilization on transpiration (E) of tomatoes at three growth stages $(\mathrm{F}=$ flowering, MF = mid-fruiting, $\mathrm{LF}=$ late fruiting $)$ in 1996 and 1997.

\begin{tabular}{|c|c|c|c|c|c|c|}
\hline \multirow[b]{3}{*}{ Treatment } & \multicolumn{6}{|c|}{$\mathrm{E}\left(\mathrm{mmol} \cdot \mathrm{m}^{-2} \cdot \mathrm{s}^{-1}\right)$} \\
\hline & \multicolumn{3}{|c|}{1996} & \multicolumn{3}{|c|}{1997} \\
\hline & $\mathrm{F}$ & MF & LF & $\mathrm{F}$ & MF & LF \\
\hline Control (0N) & $8.45 \mathrm{bc}^{2}$ & $9.56 \mathrm{c}$ & $7.93 \mathrm{~d}$ & $8.09 \mathrm{c}$ & $13.28 \mathrm{c}$ & $8.29 \mathrm{c}$ \\
\hline $\mathrm{N}$ at $90 \mathrm{~kg} \cdot \mathrm{ha}^{-1}$ & $8.85 \mathrm{ab}$ & $11.08 \mathrm{a}$ & $8.54 \mathrm{~b}$ & $7.96 \mathrm{c}$ & $14.34 \mathrm{a}$ & $10.16 \mathrm{a}$ \\
\hline $\mathrm{N}$ at $180 \mathrm{~kg} \cdot \mathrm{ha}^{-1}$ & $8.39 \mathrm{c}$ & $10.98 \mathrm{a}$ & $9.03 \mathrm{a}$ & $7.87 \mathrm{c}$ & $13.97 \mathrm{ab}$ & $9.40 \mathrm{ab}$ \\
\hline Abruzzi rye & $8.32 \mathrm{c}$ & $9.94 \mathrm{~b}$ & $8.09 \mathrm{~cd}$ & $8.75 \mathrm{a}$ & $13.26 \mathrm{c}$ & $9.40 a b$ \\
\hline Hairy vetch & $9.06 \mathrm{a}$ & $10.75 \mathrm{a}$ & $8.62 \mathrm{~b}$ & $8.45 \mathrm{~b}$ & $14.32 \mathrm{a}$ & $9.60 \mathrm{a}$ \\
\hline Crimson clover & $8.12 \mathrm{c}$ & $10.84 \mathrm{a}$ & $8.41 \mathrm{bc}$ & $8.41 \mathrm{~b}$ & $13.88 \mathrm{~b}$ & $8.72 b c$ \\
\hline
\end{tabular}

${ }^{2}$ Numbers followed by the same letter within a column are not significantly different at $P=0.05$ by least significant differences test.

\section{Literature Cited}

Abdul-Baki, A.A. and J.R. Teasdale. 1993. A no-tillage tomato production system using hairy vetch and subterranean clover mulches. HortScience 28:106-108.

Abdul-Baki, A.A., J.R. Teasdale, R. Korcak, D.J. Chirwood, and R.N. Huettel. 1996. Fresh-market tomato production in a low-input alternative system using cover crop mulch. HortScience 31:65-69.

Bohlool, B.B., J.K. Ladha, D.P. Garrity and T. George. 1992. Biological nitrogen fixation for sustainable agriculture: A perspective. Plant and Soil 141:1-11.

Boote, K. J., and N. B. Pickering. 1994. Modeling photosynthesis of row crop canopies. HortScience 29:1423-1434.

Burns, R. C. and R. W. F. Hardy. 1975. Nitrogen fixation in bacteria and higher plants. SpringerVerlag, Berlin, Germany.

Campbell, C.A., R. DeJong, and P.R. Zentner. 1984. Effect of cropping, summer fallow, and fertilizer nitrogen on nitrate nitrogen lost by leaching on a brown Chernozemic loam. Can. J. Soil Sci. 64:61-74.

Creamer, N.G., M.A. Bennett, B.J. Stinner, and J. Cardina. 1996. A comparison of four processing tomato production systems divering in cover crop and chemical inputs. J. Amer. Soc. Hort. Sci. 12:559-568.

Dorsch, M.M., R.K. Scragg, A.J. McMichael, P.A. Bighurst, and K.F. Dyer. 1984. Congenital malformations and maternal drinking water supply in rural south Australia: A case-control study. Amer. J. Epidemiol. 119:473-486.

Fred, E.B., I.L. Baldwin, and E. McCoy. 1932. Root nodule bacteria and leguminous plants. Univ. Wisc., Madison.
Frye, W.W., W.G. Smith, and R.J. Willams. 1985. Economics of winter cover crops as a source of nitrogen for no-till corn. J. Soil Water Cons. 40:246-249.

Frye, W.W., R.L. Blevins, M.S. Smith, and S.J. Corak 1988. Role of annual legume cover crops in efficient use of water and nitrogen. p. 129-154. In: J.W. Doran et al. (eds.). Cropping strategies for efficient use of water and nitrogen. Spec. Publ. No. 51. ASA-CSSSA-SSSA, Madison, Wisc.

Giller, K.E. and G. Cadisch. 1995. future benefits from biological nitrogen fixation: An ecological approach to agriculture. Plant and Soil 174:255-277.

Hallberg, G.R. 1989. Nitrate in groundwater in the United States, p. 35-75. In: R.F. Follett (ed.). Nitrogen management and groundwater protection. Elsevier, New York.

Hallberg, G.R., R.D. Libra, and B.E. Hoyer. 1985 . Non-point source contamination of groundwater in Karst carbonate aqiifers in Iowa. Perspectives on non-point source pollution. Proc. Natl. Conf. U.S. Environ. Prot. Agency, Wash., D.C.

Hargrove, W.L. 1986. Winter legumes as nitrogen source for no-till grain sorghum. Agron. J. 78:70-74.

Hobbs, S.L.A. and J.D. Mahon. 1982. Variation, heritability and relationship to yield of physiological characteristics in peas. Crop Sci. 22:773-779.

Kuo, S., E.J. Jellum, and U.M. Sainju. 1995. The effect of winter cover cropping on soil water quality, p. 56-64. Proc. W. Nutrient Mgt. Conf. Salt Lake City, Utah.

Lowrance, R. and D. Smittle. 1988. Nitrogen cycling in a multiple crop-vegetable production system. J. Environ. Qual. 17:158-162.

McVay, K.A., D.E. Radcliffe, and W.L. Hargrove. 1989. Winter legume effects on soil properties and nitrogen fertilizer requirements. J. Amer.
Soc. Hort. Sci. 53:1856-1862.

Meisinger, J.J., W.L. Hargrove, R.L. Mikkelson, Jr., J.R. Williams, and V.W. Benson. 1991. Effects of cover crops on groundwater quality, p. 57-68. In: W.L. Hargrove (ed.). Cover crops for clean water. Soil Conserv. Soc., Ankeny, Iowa.

National Research Council. 1989. Alternative agriculture. Natil. Acad. Press, Wash., D.C.

Nielsen, E.G. and L.K. Lee. 1987. The management and cost of groundwater contamination from agricultural chemicals: A national perspective. Agr. Econ. Rpt. 576. USDA Econ. Res. Serv., Wash., D.C.

Peoples, M. B., D. F. Herridge, and J. K. Ladha. 1995. Biological nitrogen fixation: An efficient source of nitrogen for sustainable agricultural production? Plant and Soil. 174:3-28.

Power, J.F. and J.W. Doran. 1988. Role of crop residue management in nitrogen cycling and use, p. 103-113. In: W.L. Hargrove et al. (eds.). Cropping strategies for efficient use of water and nitrogen. ASA Spec. Publ.51.ASA-CSSA-SSSA, Madison Wisc.

Power, J.F. and Schepers. 1989. Nitrate contamination of groundwater in North America. Agr. Ecosyst. Environ. 26:165-187.

Sainju, U.M. and B.P. Singh. 1997. Winter cover crop for sustainable agricultural systems: Influence on soil properties, water quality, and crop yield. HortScience 32:21-28.

Sainju, U.M., B.P. Singh, S. Rahman, and V.R. Reddy. 2000. Tillage, cover cropping, and nitrogen fertilization influence tomato yield and nitrogen uptake. HortScience 35:217-221.

Sainju, U.M., B.P. Singh, and W.F. Whitehead. 1998. Cover crop root distribution and its effect on soil nitrogen cycling. Agron. J. 90:511-518.

SAS Institute.1988. SAS users' guide: Statistics, Vers. 6.03. SAS Inst., Cary, N.C.

Scholberg, J., B.L. McNeal, K.J. Boote, J.W. Jones, S.J. Locascio, and S.M. Olson. 2000. Nitrogen stress effects on Growth and nitrogen accumulation by field-grown tomato. Agron. J. 92:159-167.

Smith, M.S., W.W. Frye, and J.J. Varco. 1987. Winter legume cover crops. Adv. Soil Sci. 7:95-139.

Sweeny, D.W., D.A. Graetz, A.B. Bottcher, S.J. Locascio, and K.L. Cambell. 1987. Tomato yield and nitrogen recovery as influence by irrigation method, nitrogen source, and mulch. HortScience 22:27-29.

Teasdale, T.R. and A.A. Abdul-Baki. 1995. Soil temperature and tomato growth associated with black polyethylene and hairy vetch mulches. J. Amer. Soc. Hort. Sci. 120:416-420.

University of Georgia. 1995. Commercial tomato production and management. Univ. of Georgia, Athens, Coop. Ext. Serv. Bul. 1116.

Vance, C.P. 1997. Enhanced agricultural sustainability through biological nitrogen fixation, $\mathrm{p}$. 179-186. In A. Legocki et al. (eds.). Biological fixation of nitrogen for ecology and sustainable agricultural. Springer-Verlag, Berlin, Germany.

Vigil, M.F. and D.W. Kissel. 1991. Equations for estimating the amount of nitrogen mineralized from crop residue. Soil Sci. Soc. Amer. J. 55:757-761.

Zelitch, I. 1982. The close relationship between net photosynthesis and crop yield. Bioscience 32:796-802. 